This is the version of the article accepted for publication in Feminist Theory published by SAGE: https://uk.sagepub.com/en-gb/eur/journal/feminist-theory

Accepted version downloaded from SOAS Research Online: http://eprints.soas.ac.uk/30122

\title{
Im/Possibilities of Refusing and Choosing Gender
}

\author{
Alyosxa Tudor
}

Centre for Gender Studies, School of Oriental and African Studies, University of London, UK

at53@soas.ac.uk

Intro ${ }^{1}$

The main question that I address in this article is how to conceptualise the complex im/possibilities of refusing and choosing in relation to gender? I am particularly interested in a phenomenon that can be described as lesbian haunting' (as foregrounded in this special issue): the ambivalences one will find in tracing lesbian theory in relation to transing gender. Following Avery Gordon's (2008) theoretisations of haunting, I am attempting to make sense of the ghostly presences in knowledge productions on transing gender. More specifically, in order to understand both 'gender' and 'transing gender' 2 as always already racialised, my approach relies on theories that identify 'ungendering' as an effect of racial violence (e.g. Spillers 1987, Lewis 2017, Snorton 2017). With this, it is my attempt to rethink lesbian, queer and trans feminist approaches on violence, and investigate the role of sexual violence within broader concepts of violence. Building on knowledge productions that point out the impact of racism and colonialism for constructions of gender as a binary and heteronormative

\footnotetext{
${ }^{1}$ Many thanks to Ilana Eloit and Nydia A. Swaby for their generous engagement with this article and for brilliant comments and discussions. Thank you to the anonymous reviewers and to the audience at the conference Trans in Transit in Turku, Finland, where I presented this paper in November 2018, for the invaluable questions and insights.

2 'Transing gender' in the conceptualisation I am relying on here means going beyond gender as a pre-given category, questioning binary gendering, deconstructing gender as a knowable and certain entity (e.g. Noble 2012; Stryker et al. 2008; Tudor 2017b).
} 
concept, this paper is an invitation to think through what a refusal to do what I call 'the labour of misogyny' might mean.

Lesbian theory has a complicated relationship with feminist, queer and trans studies - as indeed these strands of knowledge production have also with each other (e.g. Enke 2012; Halberstam 2011; Hemmings 2011; Wiegman 2012). This article relies on the idea that one can tell the story of these fields in ways that assume shared and divided/dividing histories. Therefore, I am concerned with analysing the ways in which lesbian, queer and feminist approaches can be seen as a synergy that works towards the transing of gender. Looking at the contradictions in lesbian feminist theorising and addressing in particular contradictory approaches to sexual violence, my analysis stresses the ambivalence that lies in the term 'haunting': haunting as the driving force that leads to relentless efforts to fight against oppression; haunting as the nightmare that keeps coming back to us; haunting as the reminder of a smouldering guilt; haunting as the impulse for radical transformation.

Lesbian Hauntings: The Lesbian/Feminist Work of Transing Gender

\section{Lesbian Transphobia}

Recent incidents like the transphobic intervention in the name of lesbians at the 2018 London Pride suggest that lesbian/dyke and trans positions are politically oppositional, mutually exclusive and antagonistic. However, many of 'us' queer feminists, lesbian feminists and trans feminists know from our own struggles, positionalities and politics that lesbian/dyke/femme/butch/ trans/non-binary can be seen as overlapping, interconnected and in complex interaction with one another. 
With an explicit focus on sexual violence, the transphobic leaflets distributed by the lesbian group Get the L Out ${ }^{3}$ at London Pride claim to oppose 'rape culture' and see lesbians erased through the existence of trans people. The UK based group Mayday4Women that endorsed the pamphlet states on its website that 'transgenderism is currently one of the biggest threats to feminism in the UK' ${ }^{4}$ Trans men and gender-nonbinary positions, so the argument goes, take away the possibility for 'women' (and for girls, in the variation that claims to protect children) to identify as women despite of being tomboy/lesbian/butch/nontraditionally feminine etc. representing. Moreover, trans women in this idea commit sexual violence by merely existing, both through their presence in women's spaces and through their claim to their own bodies as women's bodies. This reference to sexual violence as a strategy of feminist/lesbian transphobia is not new. ${ }^{5}$ We can think of Janice Raymond's vicious attack on trans people and specifically on Sandy Stone, in which she states that transwomen 'rape women's bodies by reducing the real female form to an artifact [sic]' (Raymond 1994 [1979], 104). In a similar vein, Sheila Jeffreys, in her 2014 book titled Gender Hurts, constructs transwomen as 'eternal men'. Men in this equation are the eternal perpetrators and women are eternal victims of sexual oppression, neither of them able to leave this fate that lies in the body they were born with. Needless to say, Jeffreys' approach is full of inaccuracies and inconsistencies (see Awkward-Rich 2017; Stryker/Bettcher 2016). She accuses trans people (and trans and queer feminist scholars) of gender essentialism, but she herself defines sex as a biological, eternal and universal category (Jeffreys 2014, 6). Her

\footnotetext{
${ }^{3}$ https://getthelout.wordpress.com/2018/07/05/the-journey-begins/ [15/12/2018]

${ }^{4} \mathrm{https}: / /$ www.mayday4women.com/about/ [15/12/2018]

${ }^{5}$ While I am concerned here with lesbian/feminist equations of trans existence with sexual violence, Alex Sharpe (2018) examines cases in the UK in which gender-nonconforming subjects/trans men are prosecuted for sexual assault because of not disclosing their gender history to their sexual partners. It becomes clear that the current wave of feminist transphobia in the UK is embedded in this legal discourse that sees the failure to tell the 'truth' about gender always already as sexual violence. This resonates with Sandy Stone's critical analysis in her landmark essay 'The Empire Strikes Back' (1987) in which she notes that transphobia is 'about morality tales and origin myths about telling the "truth" of gender'.
} 
understanding of social constructionism seems to exclude 'sex' and 'women' from being socially constructed, as she thinks that 'it is through their biology that [women's] subordination is enforced and maintained through rape, impregnation and forced childbearing' (Jeffreys 2014, 6). Jeffreys' central argument - trans people are clinging to essentialist stereotypical notions of gender which she sees as opposed to feminist theories of 'social constructionism' - is indeed what I would call a hostile takeover of some of feminism's key theories. Jeffreys $(2014,49)$ uses lesbian feminist theories like Wittig's - very much in contrast to my own reading of them in the next subsection or indeed to other radical lesbian readings (see Eloit 2018,26 ) - to bash theories of 'gender' in favour of the inescapability of 'sex'. The key point for my argument here is that this emphasis reinforces understandings of women's oppression as both linked to sexual violence and as written into the body. In Jeffreys' account, Gender Studies, queer theory and poststructuralist approaches have introduced 'gender' as a category to hurt women (Jeffreys $2014,3,36,41)$ and to distract from the fact that sex cannot - under no circumstances - ever - be changed or be understood to signify something else than penis=perpetrator and vagina=victim.

Many of these arguments have been used in a similar way in feminist antipornography and anti-sex-work approaches. As Wendy Brown points out in her critique of Catharine MacKinnon, understanding the category 'woman' entirely as a product of the 'eroticization of dominance and submission' $(1995,81)$, and defining the relationship of sexuality to gender only as parallel to the relationship of labour to class ${ }^{6}$, does not allow for an intersectional approach to gender.

\footnotetext{
${ }^{6}$ This means that gender is understood as a binary concept in which the dominant 'class' (men) owns 'the means' of sexuality while the oppressed 'class' (women) is forced to 'sell' - submit - their sexuality to men (in analogy to the Marxist distinction of capitalists who own the means of production and the working class who must sell their labour).
} 
Gender remains a monolithic concept unaffected by racism, ableism, classism etc. as it is only explicable in drawing analogies to class and labour but not seeing gender as already constituted through class, labour, racialisation, or geopolitical context.

The idea that transwomen are 'men in disguise' that is so often evoked in some strands of feminism, very often lesbian feminism, of course reverses or obscures the fact that transwomen like most trans, queer, gender-queer and non-binary people are consistently exposed to the sexual violence resulting from normative heterosexual cis-masculinity and its policing of others. The exclusion of transwomen from women's spaces thus reintroduces essentialist notions of the location of sexual violence. Being a man, equated with being a sexual predator, becomes written into the body of transwomen who within these ideas become 'eternal men', always trapped in the role of the male aggressor. This view not only erases the possibility of womanhood for anyone who was not ascribed girlhood at birth, it also reproduces a problematic understanding of sexual violence as inherent to male bodies. Rather than deconstructing and fighting sexual violence as a tool of power with multiple locations and manifestations, this naturalisation makes it immune to resistance.

In order to fully grasp the political choices the group Get the L Out made in distributing the leaflet at London Pride, it is important to remind ourselves that this is a corporate-sponsored mainstream event. It consists of around 500 groups, including representatives of the Royal Navy, the Metropolitan Police, the Army and in 2016, BAE, an arms manufacturer. What is striking is that in the face of this line-up of military, police and corporate forces, this lesbian group chooses to identify trans people as the 'biggest threat' to feminism. Not only does such a move favour a transphobic history of lesbian feminism over an anti-war, anti- 
police, anti-capitalist one, it also tells a story of lesbian feminism as not being able to address transnational forms of violence, including sexual violence through imperialist wars. While the group specifically targeted transwomen, they also call for an end to 'the transing of lesbians who do not conform to femininity'. ${ }^{7}$ The irony in the last statement could not be more blatant.

Lesbian feminists should know better than to single out women for not being proper women or 'hiding the truth' about their sex or gender. Have they forgotten about the many times they were assaulted for not being womanly enough or for overdoing femininity or for getting femininity wrong, for being seen as a sexual danger to straight, gender-conforming women, as the lavender menace' and a 'mannish threat' to feminism as Betty Friedan infamously put it? What are the imaginative limits to lesbian feminism that mean it seems impossible to draw a connection between their own lesbian gendernonconforming bodies and sexualities and other forms of transing gender? Is transphobia a way to eagerly prove to be a proper woman for positionalities who have been excluded from womanhood for being lesbians, for representing nonnormative genders and sexualities, for being feminists ${ }^{8}$ In the end it is their own transphobia that makes them cis-gendered. What ever happened to Wittig's lesbian, who is not a woman, and who these lesbian feminists appear to have forgotten?

\section{Inviting Wittig Back}

It is Wittig's in/famous exclamation, 'Lesbians are not women' (Wittig [1978] 1992, 32) that I want to revisit here. 'Lesbians are not WOMEN' opens up the

\footnotetext{
${ }^{7}$ https://www.mayday4women.com/2018/05/24/lets-get-the-l-out-of-here-sisters/

${ }^{8} \mathrm{In}$ a somewhat different interpretation transphobia could be seen as a haunting manifestation of lesbophobia within (some) lesbian contexts: a mode through which lesbophobia - the hatred against sexually and gender non-conforming women who are seen as failing the category and therefore are not allowed to inhabit the category-keeps haunting us.
} 
possibility of reflecting on the category of women and its exclusions and inclusions. 'LESBIANS are not women' gives us the chance to look at the interconnection of lesbian thinking, lesbian identification, lesbian sexuality and lesbian theory in relation to the category of 'women'; and 'Lesbians ARE NOT women' operates as a clear denial of belonging to the category of 'women' which moves us in the direction of questioning certainties about gender and its interconnection to sex and sexuality. As Ilana Eloit $(2018,26)$ underlines '[r]adical lesbians were foundationally inspired by Monique Wittig' and have understood Wittig's theoretisations as interventions in the French Mouvement de Libération des Femmes (MLF) that was aggressively lesbophobic and obliterated its lesbian foundations. Moreover, as Eloit compellingly points out, Wittig's thought enabled a shift of paradigms in French feminism: 'From the standpoint of their new position as non-women, radical lesbians articulated an unprecedented public discourse on 1970s feminism's exclusionary operations against lesbians, which they started calling "heterofeminism".' (Eloit 2018, 26; my emphasis). The erasure of lesbians in the MLF and with this the heterosexualisation of feminism is part of the 'ghostly history' Eloit tells (Eloit 2018,30 ) in an extensive archival work that exactly makes clear that radical lesbianism has a history of fighting against the exclusions, certainties and fixed identities of the category 'woman' and not the contrary.

For Wittig, lesbians are not women because they do not fulfil the criteria of the category in economic, political or ideological dimensions $(1992,13)$. In other words, they refuse to do the labour that misogyny requires: working for men, pleasing men, raising children, being a respected wife and mother. Wittig's utopia of a gender-free society has been much discussed: loved and hated by 
lesbians, ${ }^{9}$ taken on in Butler's Gender Trouble (2007 [1990]) and criticised and embraced by transgender studies scholars (e.g. Hale 1996; Henderson 2018; Tudor 2010). Wittig makes clear that regimes of heterosexuality - what other scholars have called 'compulsory heterosexuality' (Rich 1980) or the 'heterosexual matrix' (Butler 2007, 7) - play a crucial role in defining, stabilising and reproducing gender. I agree with Butler's warning against the 'impossible fantasy' of fully transcending power through refusal, an idea that lies in the concept of lesbians running away and leaving heterosexuality and, with this, gender behind (Butler 2007, 196). I argue, however, that we should not take Wittig too literally, but could take on the haunting that lies in this evocative exclamation: the haunting of contemporary lesbian transphobia in tension with the possibility of refusing gender. If it is possible to leave gender behind, who would stay on, who would want to stick with gender?

As Clare Hemmings points out, Butler's poststructuralist idea of gender is as much informed by Wittig's lesbian feminist materialist rejection of what I call the 'labour of misogyny' as it is by the approaches of other - gay male poststructuralists like Foucault or by psychoanalysis. However, this lesbian strand is rarely as acknowledged in the feminist and queer reception of Butler (Hemmings 2011, 179-90). Indeed, Wittig's crucial role in defining the normative (linguistic) violence of 'the straight mind' and its impact on the category 'woman' - which Butler uses centrally for troubling the automatised nexus of 'sex/gender/desire' - can be understood as complicating strict oppositions between materialism and poststructuralism (see also Tudor 2010). Hemmings $(2011,181)$ asks 'what happens when we invite Wittig back' and questions the logics of linear feminist storytelling that seem to rely on the idea that something

\footnotetext{
${ }^{9}$ See Eloit's $(2018,26)$ discussion of both positions.
} 
needs to be left behind in order to progress (Hemmings 2011, 190). 'Inviting Wittig back' can be understood as engaging one of the lesbian ghosts that haunt queer feminism: foundational to its emergence, but neglected in common representations. This can be seen as a haunting that is productive in its lingering, precisely because it has always been there, even if unrecognised (see Eloit 2018). And for my purposes here, in my desire to read trans feminist and lesbian feminist histories together rather than holding them apart, it means that queer and trans feminist approaches can be re-read (Hemmings 2011, 180) from a perspective that centres lesbian feminist approaches to heteronormative labour and its refusal as paradigmatic for queering gender and sexuality. Wittig's haunting opens up questions about the im/possible dimensions of refusing and choosing in relation to gender, and following her ghost means asking critical questions about the desire for gendered certainty and inclusion that lesbian feminist transphobia performs.

It should have become clear by now, I am speaking from a position that has difficulties even distinguishing between a dyke/lesbian and trans identification. And while this is not true for all lesbian and trans people, the desire for gendered acceptance is something that ironically links some trans and some lesbian feminist arguments. Thus affinity, empathy, identification and solidarity (see Brah 1999, 13) for different ways of politicising non-normative embodiments, sexualities and representations rather than hostility could be a uniting project. In my view, embracing Wittig's ghost has the capacity to take us beyond gender as a known and knowable entity and links this to complex analyses of power. But first we might need to ask what it is we reject, when we reject the 'labour of misogyny', and what is it we choose instead in doing so? 


\section{Decolonising Gender}

Feminist, queer and critical race approaches make clear that the concept of gender and with it womanhood is a colonial one. 'Western sex/gender systems', as Hazel Carby $(2007,123)$ puts it, are not only constructed in close interaction with racialisation but also exported through colonialism to the Global South. 'Heterosexism', Maria Lugones $(2007,186)$ underlines, can be understood 'as a key part of how gender fuses with race in the operations of colonial power'. Hortense Spillers carves out how slavery 'ungenders' both men and women, how it undoes whatever form of 'gender' had been relevant within the African societies the enslaved were taken from: "[t]hose African persons in "Middle Passage" were literally suspended in the "oceanic"' $(1987,72)$. This means, as C. Riley Snorton (2017) so convincingly points out, that trans identity, the fungibility of gender, has a racial history (and a history of racism must also be one that interrogates gender).

Bringing this back to the genealogy of Judith Butler's Gender Trouble (2007), one can read Snorton as intervening in the race-ignorant formulation of the sex/gender system (Rubin 1975). Through analysing psychoanalytical and Marxist approaches and structuralist anthropology, Gayle Rubin identifies a 'universal' mode of regulating kinship with the help of culturalised heterosexual exchange systems. These turn the female sex into gender. Butler's Gender Trouble not only deconstructs the subject of feminism and questions 'woman' as a pre-given category, but also shows (drawing on Wittig and Rubin) how sex has always been gender - how gender is not only a performative process attached 'on top of' a sexed body but influences how the sexed body comes into existence and is seen to bear meaning. With this, Butler gives us an important extension of Rubin's formulation of the 'sex/gender system'. It engages with the poststructuralist idea that normative meaning making processes construct a 
certain structure as appearing to be pre-given (rather than assuming that it is the pre-given structure from which meaning can be deduced). Analysing gynecological experiments on enslaved women and escape narratives in modernist autobiographies, Snorton $(2017,53)$ explains that Black gender, ascribed to a 'fleshed' rather than sexed body, is fungible, bears the possibility of transing. Snorton's approach, like Carby's and Donna Haraway's interventions in Rubin's universalism, makes moreover clear that the sex/gender system must be understood as a 'race/gender system' (Haraway 2007) in which 'racialized flesh' and sex are interconnected in a complex and 'bloody' relationship (Snorton 2017). Of course, sex and race are not interchangeable, nor do they have the same relation to gender. Butler's theory makes it possible to interrupt the normative nexus of 'sex/gender/desire' by pointing out the internal ruptures of this naturalised fugue. Going beyond this, Snorton $(2017,17)$ speaks of 'ungendered flesh' as opposed to 'sex': the racialised body that is disposable and violently chopped into pieces which brings 'female sex' into existence as a white concept, as the untouchable body of white femininity.

In Wittig's approach there is only sex and there is no sex at the same time. For Wittig sex is solely a category of the 'straight mind', an invention for the purpose of stabilising the economic, political and ideological order of heterosexuality: 'It is oppression that creates sex and not the contrary' (Wittig 1992, 2). This notion of 'sex', and with it the category 'women' as constructed through violence and oppression, is what I am interested here. Butler points out that Wittig's approach leads them to define sex as an object which 'has been violently shaped', and in which 'the history and mechanism of that violent shaping no longer appears' (2007, 155). In a footnote Butler remarks that this shaping could also be understood in terms of sexual violence (Butler 2007, 225). I think, however, that it is important to note that Wittig's approach is not restricted to or even 
particularly interested in sexual violence, but that Wittig understands the violence of shaping sex as a violence that lies in the consistent reproduction of dominant (gender) categories. This violence is realised through language and is both effect and result of the constant reproduction of heteronormative categories that takes place on many levels of social heterosexual interaction (Wittig 1992, 29). Bearing this in mind, I argue again that it is important to differentiate between understandings of violence - an insight that is important for intervening in transphobic lesbian feminist debates that oversimplify the connection of sex and sexual violence. First, and privileged here, understandings that define categorial violence (the violence, including sexual violence, that comes with essentialist categories) as working discursively and having a complex and contradictory relationship with the emergence of gender. ${ }^{10}$ And second, examined critically in my intervention, understandings that define sexual violence as having an automatic relation to the emergence and definition of gender (or sex, as many sexual violence based approaches argue against a focus on gender). In her insightful 1999 preface to Gender Trouble, Butler centralises the violence that cannot be reduced to sexual violence by pointing to 'the ways in which the very thinking of what is possible in gendered life is foreclosed by certain habitual and violent presumptions' (2007, viii; my emphasis). This 'normative violence', as Butler calls it $(2007, x x i)$, needs to be countered with a political movement towards legitimising 'bodies that have been regarded as false, unreal, and unintelligible' (2007, xxv). Butler speaks here of 'queer bodies' - bodies that do not fulfil dominant sexed and gendered norms: butches, femmes, trans people, faggots etc. For Butler then to counter violence, including sexual violence, the scripts of gendered and sexual normativity need to be interrupted and common cause made between and with those subjects who

${ }^{10}$ On Wittig's understanding of discursive/linguistic violence see also Tudor 2010, Karhu 2016. 
cannot easily be included in 'man' or 'woman' as fixed categories. What happens to this thought if racialisation is not seen as the mere add-on to gender and 'queer bodies' but as central to the emergence of them? The endeavor to counter normative gender violence (and within this sexual violence) certainly requires to acknowledge that both have been tools of white supremacy for centuries.

Bringing this thought back to my initial discussion of Wittig's lesbian, it turns out that it may not be so straightforward after all to revive them for queer feminist and transgender theorisations: Wittig's lesbian is an inherently white subject. Indeed, the most blatant weakness of Wittig's theory is the constant reference to lesbians as 'fugitive slaves' $(1992,20)$. In Wittig's conceptualisation, being a lesbian means rejecting the oppression that makes them into a woman. Wittig equates this with escaping slavery. Of course, as it is the case with most analogies, this one does not allow for thinking interdependencies. With the failure to think slavery in its own right, Wittig's idea of the oppressiveness of sex and of refusing to be a woman can only conceptualise a white lesbian subject. At this point, my reading differs from Kevin Henderson's who suggests that 'Wittig's materialist conception of language opens up space for thinking about how the compulsory category of sex also incites the racialization of bodies' $(2018,196)$. Wittig's analogy of the lesbian as the 'runaway slave' (in varying formulations across her work: 1992, 6, 8, 20, 30 etc.), in my view rather closes down the possibility of a nuanced analysis of the interdependencies of sex, gender and racialisation. ${ }^{11}$ Yet, how can one think of the relationship of slavery with refusing

\footnotetext{
${ }^{11}$ I am not alone with this analysis. Claire Blencowe (2011) for example speaks of 'curious absences' in Wittig's anti-biologist approach when it comes to questions of racism and supremacism. My article does not aim to give a full account of Wittig's writings, as it revisits mainly the potentials and - inseparably connected with this - the failures of the 'lesbians-are-not-women' thought. For a broader discussion of Wittig's work see Eloit (2018), and with particular focus on Wittig's concept of normative (linguistic) violence, see Tudor 2010.
} 
to do what heterosexuality requires in ways that are not reduced to an analogy? But rather in ways that recognise both the forming moment of a colonial past and the ongoing 'traumatic reality' of slavery, as Grada Kilomba $(2008,13)$ puts it? Again, having colonialism's shaping past and presence and racist regimes of power in mind, what would it mean to refuse to be a woman in a way that takes account of who is already included and excluded from that category?

While it is necessary to acknowledge slavery and the Middle Passage for contemporary understandings of the Black diaspora and the modern world order (Gilroy 1993), critical voices have warned against a collapsing of Blackness with (post)slavery (e.g. Thomas/Campt 2002, 2; Wright 2015). Michelle Wright points out that the Middle Passage Epistemology operates within 'linear spacetime' $(2015,60)$, forcing not only Black women and queers to identify with a Black male modernity, but excluding Black diasporic subjects whose histories cannot (fully) be understood through the transatlantic slave trade $(2015,27)$. What is important to take forward for the argument I am attempting to make here, however, is Gilroy's work in the Black Atlantic (1993) on the entanglement of modernity with slavery. Europe has funded its industrialisation with the transatlantic slave trade (Gilroy 1993, 64) and capitalism and all terms related to understandings of labour within capitalism cannot be thought without it (Gilroy 1993, 62). Thinking the refusal of gendered labour without these histories, indeed, strips the very idea what 'labour' is under capitalism (as well as what and who one is refusing) from its most important foundations.

What to do then with Wittig's lesbian who offers a re-thinking of refusal and choice, but who is stuck in a white feminist ignorance when the labour they consider necessary for 'womanhood' does not include deconstructing racialisation and acknowledging colonialism's shaping presence? It becomes 
clear that if one tries to escape the ties of gendered heterosexuality without acknowledging racism's foundational role in the construction of gender, the haunting that remains will certainly be a nightmarish one. My question is therefore not so much if Wittig's lesbian can be saved as a transgressive hero or if they should be doomed as problematic to the core, but rather if there is anything that can be learned from both these readings of the figure? Can we reclaim Wittig's lesbian as a figure who refuses both the heteronormative and the racialised labour that produce 'womanhood' and its exclusions, as entangled rather than analogous political projects?

The Political Power of Refusing and Choosing Gender Love Relationships

Let me begin this last part with myself. I was a lesbian once (no surprises here). And the haunting of the genderqueer migrant kid, who was not a boy, but wasn't a proper girl either, and called themself 'lesbian' in their teenage years, still leaves indelible tracks in my knowledge production. Growing up in a conservative and provincial small town in Southern Germany, I cannot say if it was being a migrant or being queer what made me so deeply confused about the rules of heterosexuality and gender. I simply could not understand the language - or maybe I should say the Southern German dialect - of normative gender and sexuality. I came of age identifying with the only political term available to me: lesbian feminist. One of the most obvious connections between lesbian-queer-trans-nonbinary-feminist is the fact that a lot of us have transitioned through these categories of self-identification, politicisation and community - not necessarily in this order, not necessarily separated from each other and not necessarily passing each category only once. In a similar vein, both Cameron Awkward-Rich and Jay Barnard formulate the relationship between 
trans and (radical) feminism in terms of love. Barnard, a programmer of the BFI Flare London LGBTQ+ Film Festival, with the event Radfem/Trans: A Love Story (March 26 ${ }^{\text {th }}, 2018$ ) carves out on screen traces of feminist controversies 'around race, sex work, porn and trans inclusion'. ${ }^{12}$ Awkward-Rich foregrounds the role rejection plays as part of many love stories: 'Love, that is, does not necessarily name a happy relation' $(2017,383)$.

Aware of this love relationship that is shaped by potential unhappiness and rejection, I have delineated my knowledge production very clearly from a collapsing of gender with oppression in strands of lesbian feminism that overdetermine the role of sexual violence for the emergence of gender. But of course, each of these terms - 'lesbian', 'sexual violence', 'feminism' are undeniably part of my history of politicisation. My analysis attempts to criticise the shortcuts 'sexual violence feminism' takes to make sense of oppression's role in the emergence of gendering. In particular, it is my goal to address the simplification of a causal approach to gender and sexual violence that leads to single-issue-politics, racism, transphobia and misogyny. Like Awkward-Rich and Barnard, who speak of love, my engagement is certainly affective. However, it turns out I am not prepared to cede the terrain of 'lesbian' to sexual violence feminists either. Moving on from my analysis of sexual violence feminism to carve out the lesbian feminist work of transing gender, I am not intending to revive lesbian feminism in its exclusionary forms or simply lament its passing as a location I could (however un/comfortably) inhabit, but rather to deal with the possibility that the lesbian feminism that had a forming role in my politicisation will keep haunting me if I do not engage with its genealogies. After all, the connection between lesbian and trans and the resulting negotiation of gender is

12 https://www.facebook.com/events/929055587273356 [16/12/2018] 
based on 'refusing to make sense' in gendered terms, as Bobby Noble (2007) puts it.

In a critical commentary on her introduction to the anthology The Lesbian Postmodern (Doan 1994), Robyn Wiegman $(2011,203)$ makes clear that her contribution back in 1994 was an attempt to "[abandon] the "lesbian" as the figure of our critical and political destination altogether'. However, in retrospect Wiegman discusses the impossibilities of complete detachment and underlines that 'we are always bound to that we try to refuse' $(2011,203)$. Awkward-Rich makes a similar point looking at transmasculine connections between feminism and trans. He reminds us that feminist and trans re-writings of the boy 'often rely on the deferral of the girl' (Awkward-Rich 2017, 836), which however, as he stresses, does not make the girl disappear.

This epistemological claim that we are 'always bound to what we try to refuse' must mean something too for the possibility to refuse gender. Butler underlines that becoming a subject is always already a process that relies on gendering and warns against a simplistic idea of deconstruction: 'Such a willful and instrumental subject, one who decides on its gender, is clearly not its gender from the start and fails to realize that its existence is already decided by gender' (1993, x; emphasis Butler). However we put it, it is evident: transing gender, gendernonbinary positions and refusing and choosing in relation to gender do not make gender disappear; instead they underline their gendered genealogies. One could read my engagement with lesbian feminism here therefore as an attempt to engage with the haunting of both the girl and the lesbian, by not letting myself reject 'her', but by re-telling the story of the lesbian in a way that requires the 
pronoun 'they'13, the lesbian I can live with, who is not a woman and who knows not only about sexual violence and about the violence of rigid gender roles, but also about desire. And whose politics make the very possibility of feminist singleissue-struggles impossible.

\section{Refusing the Labour of Misogyny}

I have always loved the exclamation 'lesbians are not women' because it allowed me to embrace my non-binary body and self - not being allowed to be a woman due to being gender-nonconforming, not wanting to be a woman as a revolutionary process based on a desire for a gender-free utopia; embracing my ambiguous gendering as a gendered way of being in the world that I desire for myself and through which I desire others. However, what is important about Wittig's exclamation is that it is not about gender representation. Even if I embrace the exclamation from a non-binary/trans position that is relatively straightforward to read as 'not-woman'14, Wittig's proposition does not only apply to butch dykes, intersex or non-binary dykes or trans masculine people (all of these identifications can be but are not necessarily connected)! High femmes and tomboy femmes or androgynous femininities - transwomen or not - are within my reading of her definition of 'Iesbian' too. It is about refusing to do the labour of heteronormativity/sexism/misogyny, remember, not (or not only)

\footnotetext{
${ }^{13}$ Interestingly, Wittig suggests 'they' as English translation for the French 'elles' pronoun in Les Guérillères, but also explains how the two produce not the same meaning (Wittig 1992, 87). With this, Wittig gives 'they' as transing pronoun a lesbian feminist history. But again, in the same section Wittig engages in violent analogies by equating the word 'women' with the N-word and with this provides another example of their absolute refusal to address racialisation/racism in its own terms (ibid., 86). Thank you to llana Eloit for reminding me of the paragraph.

${ }^{14}$ As I have pointed out elsewhere (Tudor 2017b), I consider all gendered readings as misreadings and entangled power relations complicate the possibility of reading gender straightforwardly. For example in my case, being read as a migrant has an impact on how people read my gender which indeed then never can be normative, but will always be read as non-belonging. Despite of being read as migratised, however, white privilege in my case means that people are more pre-occupied with my ambiguous gendering than with placing me within their phantasies of proper geographical/national belonging.
} 
about appearance or gender representation! This means of course that for lesbian transwomen whose political and subjective struggles entail fighting to be recognised as women, 'lesbians are not women' can mean exactly to reclaim the term 'women' as one possible way of refusing the labour of misogyny. Dealing with misogyny, with the hatred against women and femininity, also means addressing the many forms it can take: the hatred against transwomen or nonbinary people who are seen as eternal men; the hatred against femmes who are either seen as overdoing markers of femininity or not getting them right; the hatred of non-binary people, butch dykes or trans masculine people who are seen as 'mannish' 'ugly' women and therefore not available for the male gaze and heterosexual economies. In short, for some people, for some bodies, choosing femininity or choosing to be a woman is liberating, for some being forced into it is a curse, so rejection and choice and their complex negotiations can both become strategies of resistance.

In order to question simplistic ideas of femininity and masculinity that reduce gender to appearance and seem to be sure how 'seeing' and 'reading' gender works (Tudor 2017b), we need to dissect dimensions of not/womanhood and their connection to power relations like racism, migratism ${ }^{15}$, classism, ableism, queer/trans and dykephobia and misogyny. In 'Whose feminism is it anyway?', Emi Koyama (2006) points out that anti-trans feminism shares a genealogy with white feminism's single-issue-politics. Looking at feminism and its relation to the category of 'women', we can think of many examples in the history of so called 'women's' rights, which were limited to white/Western women only. Refusing to be a woman, then, must include dealing with the racial politics that lie in the

\footnotetext{
${ }^{15}$ Migratism is the power relation that ascribes migration to certain bodies and creates with this hierarchical positions of belonging to the nation. This process of migratisation works interdependently with racialisation, but is not the same (Tudor 2014, 2017a, 2018).
} 
category and the politics of racialisation that create the category. This means too that refusing to be a woman as a political act needs at times to be able to think being a woman as a privilege, for you first have to be recognised as a woman in order to be able to refuse the category. This thought makes clear that Black women and women of color, transwomen, butch dykes, gender-nonconforming, disabled and intersex persons etc. might be so fundamentally excluded from the category that being able to refuse its labour becomes the unreachable privilege. ${ }^{16}$ Awkward-Rich $(2017,836)$ speaks of the 'the added risk of both being seen as women and as failing to be so'. However, the problem of linear conceptualisation becomes evident in my formulation of this list of excluded positionalities. And indeed, positionality is important here. Through the various theoretisations it becomes clear that as a Black person, refusing racialised labour is refusing processes of being 'un-gendered', whereas as a white person refusing heteronormative labour is refusing being 'gendered'. How to think complex abjectifications within this thought? If Black women, for example, are already excluded from the category 'woman' ('ungendered' in Spillers' term), how can we make sure that within this theoretical claim, Black intersex, non-binary and trans people are not rendered abject - the impossible positions in an understanding of racialised gendering as always already excluded from normative (white) gendering? Moreover, racialisation has not only come into existence through slavery, but through many entangled, continued and discontinued regimes of colonialism, displacement and oppression. How can we analyse the ways in which racialisations that are not (or not only) connected to slavery contribute to a complex gendering and ungendering ${ }^{17}$

\footnotetext{
${ }^{16}$ Even if the linearity of language means that these positionalities appear here as a list, I understand them as overlapping and interdependent.

${ }^{17}$ As examples of reading multiple racisms together, see Day's (2015) investigation of Anti-Blackness in relation to critiques of settler colonialism, and Vimalassery, Pegues, Goldstein's (2016) endeavour of 'analyzing epistemologies of unknowing by engaging critical indigenous thought, critical race theory, postcolonial feminist
} 
Through these questions and through the genealogies I am relying on here, it should become clear that it is not my intention to replace feminist approaches that collapse the emergence of gender and sexual violence with approaches that see the im/possibilities of subject- and personhood as solely shaped by race. While critiques that see 'Afro-Pessimism' as privileging the violence of racialisation over other forms of violence could be understood as making a similar claim to my critique of 'sexual violence feminism', I think the equation is misleading. The critical race approaches cited here, that cannot be subsumed under one term and many of which I do not read as Afro-pessimist, offer much more nuanced analyses of the nexus of racialisation/gender/sexuality than the simple collapsing of gender and sexual violence I charge 'sexual violence feminism' with. The most important difference is that they conceptualise racialisation interdependently with gender and sexuality, while approaches that single out sexual violence often are monolithic. Moreover, the underlying concept of what 'violence' is differs fundamentally. Even if Saidiya Hartman who I refer to below for example is included in the body of work labelled as 'AfroPessimism', her insistence that 'race' is 'both a death sentence and the language of solidarity' $(2008,6)$ already opens up possibilities of thinking Blackness as not overdetermined by violence. ${ }^{18}$ Gail Lewis $(2017,8)$ points out that 'structurally and ideologically legitimated [racist] violence; renders the "'black woman" an oxymoron if not an impossibility'. With this, Lewis theorises the emergence of gender and its connection to violence in contrast to an understanding that sees 'women' only as the product of sexual violence. Indeed, she offers a very nuanced epistemological concept of violence that is focused on deconstructing

\footnotetext{
theory, critical disability studies, queer theory, and women of color feminism in order to trouble theorizations of settler colonialism as a stand-alone analytic'.

${ }^{18}$ For a historicisation of Afro-Pessimism through Black feminist and queer theory and therefore as antimasculinist, see Sexton 2016.
} 
the work of the normative: '[T]he capacity to generate new meaning is a function of the dynamic tension between presence and absence [of the Black woman]', underlines Lewis $(2017,15)$, and it is this 'capacity to generate new meaning', in Lewis's words, that is important to my discussion of choosing and refusing gender here.

Nael Bhanji $(2012,170)$ reminds us that trans people of color 'occupy the inhospitable territories in between... the uninhabitable "geographies of ambiguity"'. Coming from a migrant perspective, I do not shy away from metaphors of migration and displacement in conceptualising gender (see Tudor 2017b). How to make sense, then, and politically acknowledge the uninhabitability of gender-nonbinary - of not being able to be read and make oneself readable in terms that are either male or female, masculine or feminine, migrant or 'at-home'? Politically, we must be able to distinguish between gender-nonbinary which makes bodies unintelligible in gendered terms that can effect Black, brown, non-white and white persons; the claiming of gendernonbinary as an ideological strategy that does not coincide with a vulnerability (as it is seen increasingly in the generic use of the pronoun 'they'); and what Spillers calls 'ungendering' of Black people through slavery. This means that Spillers' conceptualisation of 'ungendering', the rejection of binary gender out of political conviction, and inhabiting the world as a trans person in a way that does not allow for a stable gendered reading, are not the same as all three phenomena do not generate vulnerability in the same way. Nor is their relationship of exclusion within 'womanhood' or 'gender' identical and the labour they need to refuse to effect exit the same. However, of course it is important to think 'ungendering', transing gender and gender-nonbinary in complex interdependencies. Diaspora studies scholars like Wright (2004) and Thomas/Campt (2006) make clear that the attempts of Black male intellectuals 
to re-introduce Black masculinity into the history of modernity has also made sure that heterosexuality and binary gendering were reclaimed within that normative endeavour. As Snorton (2017) and Bhanji (2012) point out, racialisation means for trans and non-binary people of color in the diaspora being constructed in multiple ways as ambivalent/non-belonging towards the dominant norm of Whiteness and gender in Western nation states. Trans feminism and Black feminism, as Kai M. Green and Marquis Bey put it, "both name, in different ways and by different inflections [...] a major problem with the category "woman" (2017, 438-9). Their overlap is, as Green and Bey compellingly make clear, about deconstructing and politicising 'an excess of categorization' $(2017,452)$.

\section{Gender Hurts?}

All these interventions show that 'gender hurts', to appropriate and re-signify Jeffreys' book title here, and many non-binary, trans, feminist and queer approaches actually deconstruct this pain and violence that comes with rigid gender regimes and racism. But what do we make of the desire for gender, for '[T]ransitive gender. Queer gender. Gender-everywhere-on-the-move' (Wiegman 2006, 90), the queer feminist pleasure that lies in performing one's own gender and desiring others as gendered beings? Wiegman's approach to gender is, like Butler's, not only focused on the normative violence of gendering but also on the pleasure that can lie in performing one's own gender and in desiring gender in others. This means understanding sexuality in terms that do not reduce it to sexual violence and gender in terms that go beyond simply seeing it in a causal relationship with oppression, while 'pleasure' and 'desire' in these accounts are not considered to be outside of the normative. For many feminists, the fight against sexual violence is the point of departure for their 
politicisation and solidarity, and yet a lot of us choose activisms and forms of knowledge production that have the ability to theorise, define and value the role pleasure plays for both gender and sexuality. Given the widespread exposure of queer, dyke, trans and non-binary people to sexual violence in institutions like families, schools, prisons etc., one certainly cannot assume that it is only sexual violence feminists who have reason to deal with the topic or that all politicisation that follows sexual violence results in approaches that deny desire and essentialise sexual difference.

Ann Cvetkovich provocatively considers whether 'incest makes you queer' and with this asks what work it could do for queer feminist resistance to 'embrace rather than refuse the links between lesbian sexual practices and sexual abuse/incest'? $(1995,358) .{ }^{19}$ Cvetkovich underlines that it is highly problematic to speculate on the causes of queerness, but on the other hand sees it as a 'missed opportunity' $(1995,357)$ not to theorise the interconnections of sexual abuse and queerness. She points out that 'there's something right, rather than something wrong' with being queer. Therefore, as she points out, a child turned queer could be re-theorised as 'welcome effects of sexual abuse' $(1995,357)$. Of course, Cvetkovich neither advocates for sexual abuse nor sees it as the cause of queerness, but theorises subjectivity and trauma in ways that do not assume having been harmed as the essence of the subject. It is the conceptualisation of lesbianism as the choice of queerness in the face of heterosexual abuse that is important about her intervention - if heterosexuality has already shown its ugly side and the romance of heterosexuality is stripped of its masks, why bother with

\footnotetext{
19 The piece in which Cvetkovich (1995) poses these questions is highly interesting due to the fact that she discusses the sex-positive art of Tribe8, a dyke punk band that frequently performed at the Michigan Womyn's Music Festival, an event that was known for its notorious exclusion of transwomen (see Koyama 2006). However, as seen in Tribe8's lead singer Lynn Breedlove's ongoing engagement in gender-nonconforming and trans politics, strategies of trans-exclusion do not prevent a transing from happening. In this case developed out of sex-positive dyke punk politics.
} 
looking for the other, less violent faces of it? She concludes: 'Perhaps we can live with the queer interdependence of that which harms and that which heals in order to embrace the unpredictable potential of traumatic experience' (Cvetkovich 1995, 357).

I want to suggest that Cvetkovich opens up a complex argument on refusing and choosing gender and sexuality and on thinking violence and desire, oppression and resistance interdependently. It becomes clear: We are more than the sum of our harms and we are always already complicit in gender. Nat Raha (2017, 632) theorises a similar thought and compellingly shows how transfeminine desire can lead to a politicisation of 'brokenness'. Saidiya Hartman focuses on these interdependencies in relation to the emergence of race when she explicates how for the Europeans 'race was invented as a hierarchy of human life' $(2008,6)$, while for those who were turned into slaves, 'race was both a death sentence and the language of solidarity' $(2008,6)$. Another angle to this entanglement is opened up in Omise'eke Natasha Tinsley's (2008) important intervention in both queer studies and black studies. Tinsley conceptualises 'queering' as refusing to cease to exist in the context of the Middle Passage. Women's love relationships on the sex-segregated decks are a "choice" of black queerness' (Tinsley 2008, 193) - a resistance to white terror, slavery and genocide. While Spillers $(1987,72)$ speaks of the erasure of gender in the oceanic, Tinsley's 'choice of queerness' is the antidote to 'ungendering': 'fluid black bodies refused to accept that the liquidation of their social selves [...] meant the liquidation of their sentient selves' (Tinsley 2008,199).

Such complex theorisations underscore my earlier argument on Wittig's use of slavery as an analogy that does not get us very far in defining the political power of refusing and choosing gender. If there is something that can be salvaged then 
from invoking Wittig's utopia of a gender-free society, it is an epistemological claim. I would suggest, relying on Hemmings' theorisation of 'feminist political ambivalence' (2018) and Jose Muñoz' (1999) concept of 'disidentification' that we accept that there is no such a thing as purity in knowledge production. Hemmings' thoughts on feminist political ambivalence help us to not try to 'clean up' $(2018,36)$ any epistemological mess, but to work productively with the contradictions that at times can feel unbearable. As Muñoz $(1999,5)$ makes clear, disidentification - the 'identification-despite' and the simultaneous refusal to identify - is a survival strategy for 'minority subjects', who cannot afford the luxury of easy and pure identification due to multiple and interdependent oppressions. Furthermore, I am completely aware of the fact that I call on scholars like Lewis and Wiegman amongst others to help me make the argument against a lesbian feminism that is engaged in single-issue-politics. Is this not beating 'lesbian feminism' at its own game, introducing anti-racist and queer feminist approaches on gender and sexuality that have previously engaged lesbian feminism in their knowledge productions in order to exactly deconstruct simplistic ideas of violence, oppression and resistance (Lewis 2005; Wiegman 1994, 2011)?

This is not to make Wiegman and Lewis into lesbian feminists, at least not more than I make myself into one. It is rather to build politics on the 'unknowable' (see Brah 1999) and the uncertainty of our own transgressive potential. Therefore, I suggest to consider the lesbian haunting to be constitutive for trans feminism, to be a transing of gender that might have been forgotten or denied, but that nevertheless does its work for feminism and queer and trans knowledge production. Acknowledging the ambivalence of all haunting, I argue that the nightmares can also be productive and force us to confront and politicise the fact of having gotten it wrong in the past (and continuing to do so in the present). 
What if we have to accept the 'queer interdependence of that which harms and that which heals' (Cvetkovich 1995, 373) in our politics and knowledge production? Is this how to turn oppression into resistance: to politicise the inescapabilties of the ambivalences of pleasure and harm, of desire and violence and of autonomy and complicity?

\section{Bibliography}

Akward-Rich, Cameron. 2017. 'Trans, Feminism: Or, Reading like a Depressed Transsexual'. Signs. 42(4): 819-841.

Bhanji, Nael. 2012. "TRANS/SCRIPTIONS: Homing Desires, (Trans)sexual Citizenship and Racialized Bodies". In: Cotten, Trystan T. (Ed.) Transgender Migrations. The Bodies, Borders, and Politics of Transition. New York: Routledge, pp. 157-175.

Blencowe, Claire. 2011. 'Biology, Contingency and the Problem of Racism in Feminist Discourse'. Theory, Culture \& Society 28(3), 3-27.

Brah, Avtar. 1999. 'The Scent of Memory. Strangers, Our Own, and Others'. Feminist Review 61, 4-26.

Brown, Wendy. 1995. States of Injury. Power and Freedom in Late Modernity. Princeton: Princeton University.

Butler, Judith. 2007. Gender Trouble. Feminism and the Subversion of Identity. New York: Routledge.

Carby, Hazel. 2007. 'White woman listen!: Black Feminism and the Boundaries of Sisterhood'. CCCS Selected Working Papers

Cvetkovich, Ann. 1995. 'Sexual Trauma/Queer Memory: Incest, Lesbianism and Therapeutic Culture'. GLQ: A Journal of Lesbian and Gay Studies 2(4): 351-377.

Day, Iyko. 2015. 'Being or Nothingness: Indigeneity, Antiblackness, and Settler Colonial Critique'. Critical Ethnic Studies 1(2): 102-21.

Eloit, Ilana. 2018. Lesbian Trouble: Feminism, Heterosexuality and the French Nation (1970-1981). Thesis submitted to the Department of Gender Studies of the London School of Economics for the degree of Doctor of Philosophy, London.

Enke, A. Finn. 2012 (Ed.) Transfeminist Perspectives in and Beyond Transgender and Gender Studies. Philadelphia: Temple University

Gilroy, Paul. 1993. The Black Atlantic. Modernity and Double Consciousness. London: Verso.

Gordon, Avery. 2008. Ghostly Matters. Haunting and the Sociological Imagination. Minneapolis University of Minnesota.

Green, Kai M. and Marquis Bey. 2017. 'Where Black Feminist Thought and Trans* Feminism Meet: A Conversation', Souls, 19(4): 438-454.

Halberstam, J. Jack. 2011. The Queer Art of Failure. Durham: Duke.

Hale, Jacob. 1996. 'Are Lesbians Women?' Hypatia, 11(2): 94-121.

Haraway, Donna. 2007. 'Gender' for a Marxist Dictionary: the Sexual Politics of a Word'. In: Parker/Aggleton (eds.). Culture, Society and Sexuality. A Reader. New York: Routledge, pp. 82-103.

Hartman, Saidiya. 2008. Lose your mother: a Journey along the Atlantic Slave Route. New York: Farrar, Straus and Giroux.

Hemmings, Clare. 2011. Why Stories Matter: The Political Grammar of Feminist Theory. Durham: Duke. 
Hemmings, Clare. 2018. Considering Emma Goldman. Feminist Political Ambivalence and the Imaginative Archive. Durham: Duke.

Henderson, Kevin. 2018. 'Becoming Lesbian: Monique Wittig's Queer-Trans-Feminism'. Journal of Lesbian Studies, 22(2): 185-203.

Jeffreys, Sheila. 2014. 'Gender Hurts: A Feminist Analysis of the Politics of Transgenderism. Oxon: Routledge.

Karhu, Sanna. 2016. 'Judith Butler's Critique of Violence and the Legacy of Monique Wittig'. Hypatia, $31,827-843$.

Kilomba, Grada. 2008. Plantation Memories. Episodes of Everyday Racism. Münster: Unrast.

Koyama, Emi. 2006. 'Whose Feminism is it Anyways?' In: Stryker/Whittle (eds). The Transgender Studies Reader. Routledge.

Lewis, Gail. 2017. 'Questions of Presence'. Feminist Review 117: 1-19.

Lugones, Maria. 2007. 'Heterosexualism and the Colonial/Modern Gender System'. Hypatia 22(1): 186219.

Muñoz, Jose. 1999. Disidentifications. Queers of Color and the Performance of Politics. Minneapolis: University of Minnesota.

Noble, Bobby 2012. 'Refusing to Make Sense'. Journal of Lesbian Studies 11 (1-2)" 167-175.

Noble, Bobby 2012. 'Trans. Panic. Some Thoughts toward a Theory of Feminist Fundamentalism'. In: Enke, A. Finn (ed.), Transfeminist Perspectives in and Beyond Transgender and Gender Studies. Philadelphia: Temple University, pp. 45-59.

Raha, Nat. 2017. 'Transfeminine Brokenness, Radical Transfeminism'. South Atlantic Quarterly, 116(3): 632-646.

Raymond, Janice. 1994. The Transsexual Empire. The Making of the She-Male. New York: Teachers College Press.

Rubin, Gayle. 1975. 'The Traffic in Women' In Rayna R. Reiter (ed.), Toward an Anthropology of Women. Monthly Review Press, pp. 157-210.

Sexton, Jared. 2016. 'Afro-Pessimism: The Unclear Word'. Rhizomes: Cultural Studies in Emerging Knowledge 29, 1-21.

Sharpe, Alex. 2018. Sexual Intimacy and Gender Identity 'Fraud'. London: Routledge.

Snorton, C. Riley. 2017. Black on Both Sides: A Racial History of Trans Identity. Minneapolis: University of Minnesota.

Spillers, Hortense. 1987. 'Mama's Baby, Papa's Maybe: An American Grammar Book'. Diacritics 17(2): 65-81.

Stone, Sandy. 1987. 'The Empire Strikes Back: A Posttranssexual Manifesto'. https://sandystone.com/empire-strikes-back.pdf

Stryker, Susan; Currah, Paisley; Moore, Lisa Jean (2008): 'Introduction: Trans-, Trans, or Transgender?'. In: WSQ: Women's Studies Quarterly. 36(3-4): 11-22.

Stryker, Susan; Bettcher, Thalia M. 2016. 'Introduction' TSQ: Transgender Studies Quarterly 3(1-2), 514.

Thomas, Deborah A.; Campt, Tina M. (2006): 'Diasporic Hegemonies: Slavery, Memory, and Genealogies of Diaspora'. Transforming Anthropology. 14(2): 163-172.

Tinsley, Omise'eke Natasha. 2008. "BLACK ATLANTIC, QUEER ATLANTIC: Queer Imaginings of the Middle Passage". GLQ: A Journal of Lesbian and Gay Studies. 14(2-3): 191-215.

Tudor, Alyosxa (2010) 'Wittig - Sprache als Intervention, Intervention in Sprache.' In: Kuch/Herrman (eds.), Philosophien sprachlicher Gewalt: 21 Grundpositionen von Platon bis Butler. Weilerswist: Velbrück, pp. 331-350.

Tudor, Alyosxa. 2014. from [al'manja] with love: Trans_Feministische Positionierungen zu Rassismus und Migratismus. Frankfurt a.M.: Brandes \& Apsel. 
Tudor, Alyosxa. 2017a. 'Queering Migration Discourse. Differentiating Racism and Migratism in Postcolonial Europe'. Lambda Nordica, 22(2-3): 21-40.

Tudor, Alyosxa. 2017b. 'Dimensions of Transnationalism'. Feminist Review 117: 20-40.

Tudor, Alyosxa. 2018. 'Cross-Fadings of Racialisation and Migratisation: The Postcolonial Turn in Western European Gender and Migration Studies'. Gender, Place and Culture 25(7), 10571072.

Vimalassery, Manu and Juliana Hu Pegues and Alyosha Goldstein. 2016. 'Introduction: On Colonial Unknowing.' Theory \& Event 19, 4.

Wiegman 1994, 'Introduction: Mapping the Lesbian Postmodern'. In: Doan (Ed.). The Lesbian Postmodern. New York: Columbia University.

Wiegman, Robyn. 2006. 'Interchanges: Heteronormativity and the desire for gender. Feminist Theory 7(1): 89-103.

Wiegman, Robyn. 2011. 'Afterword: The Lesbian Premodern Meets the Lesbian Postmodern'. In: Giffney/Sauer/Watt (eds.). The Lesbian Premodern New York: Palgrave.

Wiegman 2012, Object Lessons. Durham: Duke.

Wittig, Monique. 1992. The Straight Mind and Other Essays.

Wright, Michelle. 2004. Becoming Black. Creating Identity in the African Diaspora. Durham: Duke.

Wright, Michelle. 2015. Physics of Blackness. Beyond the Middle Passage Epistemology. Minneapolis: University of Minnesota. 